\title{
INTERAKSI INTERNASIONAL DALAM PERSPEKTIF "DETERMINISME" GEOGRAFI: PANDANGAN DAN KRITIK
}

\author{
Mohammad Maiwan \\ Dosen Jurusan IImu Sosial Politik FIS UNJ \\ .Email: mmaiwan@yahoo.com
}

\section{PENDAHULUAN}

Dalam studi hubungan internasional interaksi di antara negara-negara berdaulat menempati posisi penting dalam konstelasi politik global. Sejauh ini, seperti yang dikemukakan oleh banyak ahli, pembahasan tentang interaksi internasional pada tingkat pemerintah difokuskan pada bagaimana cara negara-negara berurusan satu sama lain, dalam bentuk instrumen-instrumen apa yang digunakan, pendekatan mana yang dipilih, serta bagaimana cara menetapkan pilihan kebijakan tersebut. Sebagaimana layaknya kehidupan bertetangga di masyarakat, kehidupan dalam tataran negara di tingkat internasional tidak saja bersifat formal tetapi juga informal. Adakalanya hubungan satu negara dengan negara lain dilandasi oleh sebatas keinginan normatif yang biasa, saling menghormati dan menguntungkan sampai kepada tindakan untuk mempengaruhi perilaku negara .

Dalam hubungan seperti itu, institusi atau aktor negara tidak selamanya memiliki pengaruh yang otonom, melainkan dibentuk oleh aktor-aktor politik lain semisal organisasi antarpemerintah yang sering dianggap sebagai kerangka institusional tempat berlangsungnya interaksi antarnegara. Lembaga-lembaga antar pemerintah ini, seperti: PBB (Perserikatan Bangsa-Bangsa) dan ASEAN (Perhimpunan Bangsa-Bangsa Asia Tenggara), Bank Dunia dan sejenisnya misalnya, sering menyajikan setting untuk urusan negara-negara, baik sebagai forum pembahasan, maupun sebagai instrumen yang digunakan untuk mewujudkan keinginan anggota-anggotanya. Meskipun demikian, institusi negara masih tetap merupakan aktor utama yang menentukan kebanyakan arah interaksi internasional.
Secara umum, interaksi internasional dipengaruhi oleh berbagai faktor yang kemudian menjadi landasan lahirnya sejumlah pandangan atau perspektif teoritik. Salah satu perspektif yang terkenal adalah perspektif geografi. Perspektif ini memandang interaksi internasional dipengaruhi kedudukan wilayah atau setting geografis suatu negara, sekaligus membentuk perilakunya. Pandangan ini kemudian diserap aliran behavioral dalam studi-studi mereka yang tumbuh pesat sejak tahun 1950-an. Untuk menjelaskan apa pijakan ilmiah dan argumen-argumen perspektif geografis ini, serta kekuatan dan kelemahan pandangan "deterministik" mereka dalam konteks hubungan internasional, maka artikel ini akan mengemukakan lebih jauh.

\section{TELAAH PUSTAKA}

Di kalangan para sarjana geografi, khususnya geografi politik, karya-karya klasik yang menegaskan hubungan antara politik internasional dan faktor-faktor ekologi bisa dibagi ke dalam empat kelompok. Kelompok yang pertama adalah buku-buku yang menyajikan informasi geografis tentang kasus-kasus tertentu, misalnya Boyd Andrew (1964). Kedua adalah, usaha-usaha ahli geografi untuk menguraikan dampak umum geografi terhadap politik seperti Cole (1963). Ketiga adalah karya-karya ahli geopolitik seperti MacKinder (1962), Saul Cohen (1963), dan Kane (1971) yang berusaha meramalkan dan menunjukkan kebijakan berdasarkan postulat-postulat geografis.

Kategori terakhir atau kelima terdiri atas karya-karya yang berupaya untuk mengidentifikasi dampak perubahan kondisi sosial dan teknologi yang telah mengubah hubungan manusia dengan lingkungan 
biofisiknya. Contoh dari jenis kajian ini adalah karya Sprout dan Sprout (1963) yang berusaha membuat suatu kerangka umum untuk mempelajari implikasi-implikasi perkembangan ekologi terhadap politik internasional. Sementara itu Falk (1971) bahasannya terutama difokuskan pada apa yang dianggapnya sebagai bahaya-bahaya penggunaan metode kontemporer untuk menangani masalah-masalah lingkungan. Selanjutnya Taubenfeld and Taubenfeld (1969), Rowlands (2005), yang mengidentifikasi implikasi perkembangan tertentu di satu bidang, seperti modifikasi cuaca terhadap politik internasional.

Kajian para ahli di atas membentuk suatu kerangka pandangan yang cukup menarik dalam mengkaitkan sejauh mana dimensi spatial mempengaruhi perilaku aktor negara dan memberikan kerangka kebijakankebijakan politik internasional yang diambilnya. Akan tetapi, meskipun dimensi politik internasional tidak saja dibentuk oleh persepsi-persepsi yang berpijak pada aspek setting alamiah kewilayahan, namun hakikatnya dimensi itu tidak bisa dihilangkan. Pentas politik internasional yang diwarnai oleh berbagai bentuk hubungan, mulai dari proses tawar menawar (negosiasi), dukungan, tuntutan, ancaman, sampai dengan perang sekalipun, ternyata -untuk sebagian-- secara seksama memperhitungkan dan dibentuk oleh citra kewilayahan itu.

\section{Interaksi Internasional: Perilaku Negara dan Konteksnya}

Perilaku suatu negara dalam hubungannya dengan negara lain tidak bisa dipisahkan dari konteks internasional yang melahirkan sistem internasional yang ada. Dua aliran teori dalam studi hubungan internasional, yakni geopolitik dan realisme, telah membahas aspek ini secara panjang lebar dan mendalam. Teori-teori yang menjelaskan perilaku negara yang menitikberatkan pada konteks geografis bukanlah suatu gejala baru. Hal ini bisa dilacak jauh ke belakang. Pada abad ke-4 seorang filosof India yang bernama Kautilya membahas suatu teori tentang perilaku negara yang sebagian didasarkan atas geografi dengan membayangkan sebagai (Russell 2003:45):

"...suatu lingkaran (yang terdiri atas) negara-negara yang membentuk sejenis sistem tata surya politik, dan cenderung saling bergravitasi sebagai sahabat atau bertabrakan sebagai musuh sesuai dengan posisi masingmasing dalam lingkaran tersebut. Jadi, negara-negara yang saling berbatasan, dan karena itu sesuai dengan sifatnya akan mempunyai banyak sekali titik gesek, harus dianggap sebagai musuh alami."

Dengan berasumsi bahwa negaranegara akan berusaha memperluas wilayahnya, Kautilya berargumentasi bahwa negara-negara yang bertetangga akan selalu menjadi musuh, dan "tetangganya tetangga" akan merupakan sahabat. Meskipun teori beliau itu jauh lebih kompleks, para ahli geopolitik setelah abad-abad itu dan belakangan, seperti Alfred T. Mahan yang menekankan kekuatan laut serta Sir Harolford McKinder yang menekankan kekuatan darat, telah meremehkan pentingnya konteks geografis.

Pada abad ke-20 tekanan yang sempit dari para ahli geopolitik pada geografi ini diperluas menjadi pendekatan "realis". Realis seperti Hans J. Morgenthau (2012) berargumentasi bahwa setiap negara memiliki hubungan tertentu dengan lingkungan internasional yang ditetapkannya sebagai seperangkat kepentingan nasional yang "obyektif". Kepentingan nasional ini dianggap menentukan politik luar negeri suatu negara. Dalam kaitan ini, geografi masih penting karena banyak kaitannya dengan penetapan kepentingan nasional, tetapi faktor-faktor lain dari aspek kekuatan militer sekarang masuk ke dalam rumusan itu. Menurut pendekatan ini, negara-negara kecil hanya bisa menjalankan kebijakan bersekutu dengan negara-negara yang paling cenderung melindunginya. Meskipun demikian, pandangan ini tidaklah bersifat 
konstan mengingat sistem dan dinamika politik internasional cenderung berubah.

Faktor-Faktor yang Mempengaruhi

Selain permusuhan dan persahabatan, ada seperangkat faktor lain yang menentukan hubungan antarnegara. Perangkat faktor ini dapat kita sebut sebagai penting baginegara yang bakal menjadi tuan rumah dari negara pengirim duta atau utusan. Karena itu, persoalan yang penting adalah, apa yang membuat suatu negara penting bagi negara lain,serta dimensidimensi apa yang mempengaruhinya. Dalam kaitan ini, ada tiga faktor penting yang mempengaruhi interaksi internasional, yakni: Letak geografis, hubungan ekonomi, dan ikatan historis.

Letak geografis ini sangat penting. Perbatasan atau wilayah perairan bersama menimbulkan situasi-situasi yang harus ditangani secara rutin. Bahkan di masa lalu ketika era Perang Dingin negara-negara yang bermusuhan, seperti Jerman Timur dan Jerman Barat, terpaksa harus mengadakan berbagai interaksi rutin karena mereka memiliki perbatasan bersama (Muir 2006:92). Begitu juga dengan Korea Utara dan Korea Selatan sekarang ini. Apabila kedua negara bersahabat, seperti halnya Amerika Serikat dan Kanada, memiliki perbatasan bersama akan menimbulkan interaksi rutin yang lebih banyak dan lebih beragam. Demikian pula, makin jauh jarak suatu negara dengan negara lain makin sedikit pula interaksi rutinnya, kecuali negara itu memiliki letak geografis yang strategis, seperti negara Mesir dengan Terusan Suez yang dimilikinya.

Dewasa ini peningkatan interaksi di antara negara-negara diwarnai dengan kecenderungan regionalisasi, yang merupakan pelembagaan kepentingan supranasional berdasarkan garis-garis regional yang hanya melibatkan negaranegara yang berada di dalam kawasan tertentu. Kelihatan, "politik" suatu wilayah geografis tertentu (misalnya Eropa Barat, Timur Tengah, Asia Pasifik, Afrika subSahara, Asia Selatan, Asia Tenggara,
Amerika Latin) meneguhkan kedudukan geografis sebagai basis tawar menawar dalam sistem politik internasional, sekaligus fragmentasi kepentingan yang mencolok (Slowe 2009:83-84). Hal tersebut merupakan konsekwensi alamiah dari pertumbuhan negara yang semakin banyak. Kondisikondisi geografis cenderung makin mengikat kepentingan negara-negara di dalam wilayah geografis tertentu, di mana arena itu menciptakan kondisi-kondisi yang mengakibatkan kompetisi dan tawar menawar di antara negara-negara makin kuat.

Keadaan ini, bagi organisasi universal seperti PBB (Perserikatan Bangsa-Bangsa) memberikan dampak yang ambigu. Di satu pihak, organisasi-organisasi regional tersebut mempersatukan negara-negara di seluruh dunia dan menyajikan suatu pentas interaksi di antara bangsa-bangsa, namun di lain pihak ada suatu kecenderungan yang jelas bagi negara-negara yang berasal dari kawasan yang sama untuk lebih sering berinteraksi dan memberikan dukungan suara bersama-sama di PBB. Dukungan bersama dalam forum PBB ini mencerminkan bahwa solidaritas kewilayahan menjadi landasan strategis dalam interaksi setiap negara

Hubungan ekonomi juga mempengaruhi jumlah dan jenis interaksi rutin. Perdagangan timbal balik yang padat menimbulkan kondisi-kondisi bagi interaksi rutin yang luas dan bervariasi bukan saja karena banyaknya tipe masalah administratif yang bisa ditimbulkan oleh volume perdagangan yang cukup besar, melainkan juga karena negaranegara yang terlibat banyak dipengaruhi oleh kebijakan-kebijakan ekonomi masingmasing. Lebih dari itu, usaha-usaha negara terbelakang untuk memperluas pasar dan investasi modal di negara-negara maju menyebabkan mereka mengirimkan misi diplomatiknya ke negara-negara itu.

Ikatan historis juga menjadi faktor penentu yang memperbesar jumlah interaksi rutin antarnegara. Sebagai contoh, ikatan kolonial memberikan kontribusi bagi 
terbentuknya berbagai interaksi rutin bagi negara-negara seperti Inggris dan negaranegara bekas jajahannya. Baik Inggris maupun Perancis memang telah membentuk suatu organisasi antarpemerintah yang strukturnya longgar yang anggotaanggotanya adalah negara-negara bekas jajahannya. Organisasi Persemakmuran Inggris dan Masyarakat Perancis merupakan perwujudan interaksi rutin yang luas antara negara bekas jajahan dengan bekas penguasanya. Hubungan-hubungan historis lainnya, seperti Amerika Serikat di Amerika Latin dan Rusia di Eropa Timur, menyebabkan jumlah dan variasi interaksi rutin dengan negara-negara di kawasan tersebut jauh lebih besar daripada yang kita duga.

Salah satu faktor tambahan yang penting yang mempengaruhi kuantitas dan keragaman interaksi rutin antarnegara adalah sumberdaya ekonomi yang tersedia.Dewasa ini, ada lebih dari 210 negara di dunia. Akan tetapi banyak negara yang tidak mampu mengadakan hubungan diplomatik dan bentuk hubungan rutin lainnya dengan semua negara. Negara-negara dengan tingkat ekonomi yang rendah dan stabilitas politik yang rentan secara mencolok menempati kategori ini, seperti: Somalia, Ethopia, Burundi, Afghanistan, Timor Leste, Suriah, Lybia, Yaman, dan sejenisnya.

Dalam kaitan ini, Alger dan Brams (Russel 2003:41) menemukan bahwa "30 negara mengirimkan diplomatnya hanya kepada 10 sampai 29 negara lain". Lebihlebih para diplomat sering "merangkap" dengan bertugas sebagai pemimpin misi diplomatik di dua atau lebih negara. Misalnya, banyak duta besar Afrika untuk Amerika juga merangkap sebagai perwakilan mereka di Perserikatan Bangsa-Bangsa. Oleh karena itu, beberapa negara mempunyai staf paruh waktu di negaranegara di mana mereka memiliki misi. Jadi, besarnya biaya untuk misi diplomatik membuat sejumlah negara melakukan efisiensi dengan memangkas anggaran maupun mengangkat personel secara terbatas dengan tugas yang rangkap

\section{Analisis Pentingnya Faktor Geografis}

Secara umum dapat dikemukakan bahwa faktor geografis memiliki kedudukan penting dalam hubungan internasional. Meskipun kita harus waspada terhadap determinisme geografis, pernyataan yang dikemukakan oleh Saul B. Cohen, seorang ahli geografi politik dapat menjadi petunjuk yang mengilustrasikan pentingnya geografi dalam hubungan-hubungan politik luar negeri antarnegara. Cohen (1963:61-62) memberikan gambaran berikut:

"Dua kondisi lokasi yang mendasar menandai posisi geopolitik Uni Soviet dan Amerika Serikat. Pertama, kedua negara adidaya ini tumbuh dalam keadaan fisik terisolasi satu sama lain. Secara fisik kedua-duanya masih jauh kecuali dalam waktu ruang menurut pengertian abad angkasa. Kedua, Uni Soviet berada dalam hubungan langsung melalui daratan atau laut yang sempit dengan banyak negara berdaulat; Amerika memiliki sedikit tetangga.Kondisi yang pertama bisa membantu menjelaskan mengapa Perang Dingin tidak meletus menjadi perang tembak-menembak. Kondisi kedua menegaskan fakta bahwa Uni Soviet sangat memprioritaskan hubungan-hubungan militer dengan negara-negara tetangganya, sementara keamanan Amerika Serikat tidak akan bisa dicapai jika hanya melalui hegemoni militer atas negaranegara tetangganya"

Jadi hubungan-hubungan ruang yang ditentukan oleh ekologi merupakan bagian penting dari setting interaksi antarnegara pada semua tingkat. Selain itu, setting ekologis ini juga menyangkut distribusi sumberdaya. Misalnya, lokasi sumbe rdaya alam seperti batu bara, baja, dan minyak sangat mempengaruhi cara negara-negara berurusan satu sama lain. Selain itu, yang sama pentingnya adalah lokasi sumber daya manusia; tidak hanya jumlahnya, tetapi juga 
tingkat keterampilan dan pendidikannya. Seperti yang terlihat dalam banyak kasus negara, kemampuan ekonomi dan militer mempengaruhi cara negara-negara berperilaku. Hal ini berarti bahwa distribusi sumberdaya juga memainkan peran penting.

Meskipun faktor-faktor ekologis signifikan sebagai kerangka bagi interaksi antarnegara, namun perannya "tidaklah sama" untuk jangka waktu panjang (Gotmann 2003:47). Kadang-kadang salah mengasumsikan bahwa lokasi dan distribusi sumberdaya merupakan fakta-fakta nyata dan tetap statis. Namun asumsi seperti itu tidak bisa memperhitungkan sifat dinamis dalam saling mempengaruhi antar manusia dan lingkungan biofisiknya. Suatu saling pengaruh yang tidak hanya timbul akibat perkembangan teknologi, tetapi juga akibat munculnya pola-pola kehidupan sosial, ekonomis, dan politis.

Dampak faktor teknologi terhadap kehidupan moderen telah mengubah setting ekologis itu. Dengan semakin cepatnya arus komunikasi dan transportasi, teknologi telah mempengaruhi peran lokasi. Hal ini terwujud, misalnya, dalam perubahan formulasi strategi militer selama 300 tahun yang lalu. Pengendalian laut jauh lebih penting artinya pada abad ke 18 dan ke 19 daripada sekarang. Inggris bisa melindungi diri melalui kekuatan lautnya sampai perubahanperubahan teknologi tertentu membuat kekuatan udara lebih penting daripada penguasaan laut (Muir 1981:29).

Perbedaan besar antara politik luar negeri Amerika Serikat sebelum Perang Dunia I dan sesudah Perang Dunia II merupakan contoh yang jelas tentang ketidakstabilan kondisi-kondisi geografis. Sebelum Perang Dunia I kebijakan untuk tidak terlibat dalam masalah-masalah Eropa tampaknya merupakan kebijakan yang masuk akal. Samudera Atlantik dipandang, dengan beberapa alasan, sebagai rintangan yang melindungi Amerika Serikat. Namun, setelah Perang Dunia II, ketika jelas bahwa Atlantik dapat diseberangi dengan cepat, politik isolasionis tidak begitu mudah dipertahankan. Persepsi terhadap kendala geografi dan jarak kemudian berubah (Muir 1981:37).

Keseluruhan dampak teknologi terhadap faktor-faktor ekologis ini adalah mengurangi pengaruh kendala jarak bagi negara-negara yang teknologinya maju. Pesatnya peningkatan kemampuan manusia untuk bergerak, komunikasinya, barang-barang ekonominya, dan kekuatan militernya menempuh jarak jauh dalam waktu singkat telah mengubah wajah dunia kontemporer. Makin meningkatnya interdependensi ekonomi dan militer di antara negara-negara di seluruh bagian dunia sebagian bisa dijelaskan oleh dampak teknologi terhadap pengaruh jarak.

Teknologi juga sangat mempengaruhi distribusi sumberdaya, tidak hanya dengan mudahnya menemukan berbagai bahan mentah karena semakin baiknya transportasi, tetapi juga dengan membuat sumber daya yang tadinya tidak berguna menjadi sangat bernilai. Batu bara, besi, dan minyak tidak menjadi penting sebelum kemampuan untuk mengggunakan sumber daya itu dikembangkan. Sebelum abad ke 19, emas dan logam berharga lainnya dianggap sebagai sumnber daya alam yang paling bernilai. Namun, dewasa ini sumberdaya energi telah mengungguli arti penting logam berharga dalam urusan negara. Demikian pula orang-orang yang terampil dan berpendidikan (sumber daya manusia) dijadikan bernilai oleh revolusi industri.

Selain itu, perkembangan teknologi telah menciptakan alat-alat baru untuk menemukan dan memperoleh sumber daya alam. Metode-metode kasar dalam menemukan dan menambang pada abad ke 19 sekarang telah diganti dengan metodemetode yang sangat canggih dan sangat efektif. Misalnya minyak di berbagai negara Arab dewasa ini menjadi penting karena adanya teknik pengeboran minyak di daratan telah dikembangkan sedemikian maju. Juga minyak di wilayah Laut Utara di negaranegara Skandinavia yang mendekati Kutub 
Utara yang bahkan bisa ditambang dengan cara yang lebih canggih belakangan ini. Begitu juga ditemukannya minyak serpih di Amerika Serikat sekarang ini. Semua itu kelak mencetuskan peta baru kemampuan negara-negara.

Perubahan pola-pola ekonomi, sosial, dan politik juga telah mengubah hubungan manusia dengan lingkungan biofisisnya sampai taraf di mana ancaman-ancaman fisis dan biologis yang mendasar telah berkembang (Buck 2007:21). Masalah ledakan penduduk, polusi udara dan air, juga pengendalian penyakit dan pelestarian sumber daya fisis dan biologis menimbulkan masalah dan tantangan yang tidak bisa dipecahkan tanpa adanya kerjasama internasional. Selain mengubah tujuan dan alat-alat konflik, revolusi dalam setting ekologis juga menyajikan bidang yang luas di mana negara-negara bisa dan memang harus bekerjasama.

Jadi, karena hal ini faktor-faktor ekologis sedang mengubah setting interaksi antarnegara. Kondisi-kondisi tradisional telah diubah secara radikal oleh dampak teknologi terhadap hubungan manusia dengan lingkungannya. Para pengambil keputusan sering kurang menghiraukan perubahanperubahan itu dan terlena oleh diktum-diktum lama yang telah usang. Akibatnya beberapa negara meleset dan salah langkah mengambil keputusan. Dengan menggunakan kerangka penetapan situasi internasional dan politik luar negeri sebagai "tindakan rasional dan intelektual" serta "pemecah masalah", maka citra mereka tentang hubungan antara daratan, waktu, dan kekuatan militer atau kondisi-kondisi ekonomi tidak bisa disesuaikan dengan perubahan-perubahan yang diakibatkan oleh faktor-faktor teknologi.

Sebagai contoh, sebelum Perang Dunia II, para pengambil keputusan Perancis menduga bahwa kondisi militer pada dasarnya masih sama dengan kondisi sebelum Perang Dunia I. Karena tidak mampu memperhitungkan dampak perubahan teknologi demikian, seperti pesawat terbang dan satuan lapis baja, angkatan darat Perancis tidak mampu menangkal kekuatan militer Jerman yang digelar dalam Perang Dunia II (Mellor 2009:108-109). Maka dampak faktor ekologis terhadap interaksi antarnegara tidak hanya menyangkut cara teknologi dan kondisikondisi lain mempengaruhi faktor-faktor geografis, tetapi juga menyangkut kemampuan para pengambil keputusan dan policy influencers mereka untuk menyesuaikan citra mereka dengan kondisikondisi ekologis yang baru.

Bagi sejumlah negara dengan tingkat kesiapsiagaan yang tinggi kondisi itu tidak akan dibiarkan, dan tidak akan pernah menganggap remeh perkembangan teknologi sekecil apapun. Contoh paling mutakhir dalam hal ini adalah Israel. Ditemukannya teknologi pesawat nirawak berupa drone, yang bisa diterbangkan dan dikontrol dari jarak jauh mengakibatkan batasan-batasan keamanan secara konvensional berubah total. Sebagai suatu negara kecil yang dikelilingi musuh-musuh Arabnya, Israel secara cekatan mencermati ini dengan mengembangkan perisai tandingan untuk menghancurkan drone, sebelum masuk ke wilayahnya. Senjata ini di masa mendatang akan dapat dengan mudah "dikirimkan" faksi-faksi perlawanan di Palestina seperti, Hamas dan Fatah maupun Hezbollah di Lebanon, serta kelompokkelompok perlawanan yang lain. Bagi Israel, secara psikologis penetrasi drone, telah melahirkan "efek penggetar" (deterrence effect) yang secara dini harus diimbangi dengan tindakan apapun.

Dengan demikian, dimensi teknologi memberikan pengaruh penting dalam merubah konstelasi serta geopolitik internasional secara menonjol. Dewasa ini daya jangkau dan efektifitas teknologi jelas melampaui bayangan para pengambil kebijakan politik luar negeri beberapa puluh tahun yang lalu. Determinasi teknologi telah menggeser diktum-diktum hubungan internasional pada level yang paling sederhana sekalipun, sehingga melahirkan 
mode dan tatacara hubungan baru di antara negara-negara dalam lanskap politik yang berubah dengan cepat (Viotti and Kauppi 1993:66-67). Secara teoritik kemampuan interaksi suatu negara bukan lagi ditentukan oleh kemampuan-kemampuan alamiahnyayang bersifat endowment saja, seperti; geografi, sejarah, kultur, tradisi, penduduk, dan lain-lain, tetapi juga kecekatannya dalam memanfaatkan teknologi.

Namun demikian, dimensi teknologi tidaklah berpengaruh secara mutlak. Sampai hari ini, sekali lagi, dapat dikemukakan bahwa,faktor geografi masih memainkan peranan penting dalam analisa politik internasional. Berbagai kebijakan luar negeri yang diambil suatu negara pada hakikatnya tidak bisa sepenuhnya mengeleminir pertimbangan-pertimbangan geografi. Setting kewilayahan melahirkan suatu citra tertentu bagi perilaku politik negara dalam berhubungan dengan negara lain (Muir and Paddison 1981), (Agnew 1987). Sampai hari ini, beberapa kondisi geografis masih merupakan bagian yang konstan dari keputusan-keputusan politik luar negeri. Sebagai contoh, terusan-terusan dan jalurjalur pelayaran seperti: Terusan Suez, Panama, Giblaltar, Selat Malaka, Selat Hormuz, Semenanjung Aden, Laut China Selatan, masih sangat penting, kendati di antaranya untuk sebagian sudah jauh berkurang perannya dibanding masa-masa lalu.

Seperti dikemukakan dalam studi-studi di kalangan banyak pakar, sebagian diantaranya dengan menggunakan pendekatan-pendekatan kuantitatif yang menakjubkan, bagaimana dimensi perilaku negara, proksimitas atau kedekatan geografis berhubungan dengan perdagangan antarnegara, perilaku pemberian suara di $\mathrm{PBB}$, meningkatnya regionalisme, serta keanggotaan bersama dalam organisasiorganisasi antarpemerintah, serta eratnya hubungan antar wilayah seperti Eropa Timur dan juga negara-negara Arab. Semuanya itu menunjukkan setting geografi tetap menjadi bagian penting dalam domain politik internasional yang tidak bisa dibantah.

\section{PENUTUP}

Secara umum, interaksi internasional dipengaruhi oleh berbagai faktor, yakni letak geografis, hubungan ekonomi, dan ikatan historis, serta sumber daya ekonomi yang tersedia. Perspektif geografi memandang interaksi internasional dipengaruhi kedudukan wilayah atau setting geografis suatu negara, sekaligus membentuk perilakunya, serta memberikan kerangka kebijakan internasional yang diambilnya.

Akan tetapi, meskipun faktor-faktor geografis signifikan sebagai kerangka bagi interaksi antar negara, namun perannya "tidaklah sama" untuk jangka waktu panjang. Faktor ini kurang memperhitungkan sifat dinamis dalam saling mempengaruhi antar manusia dan lingkungan biofisiknya, akibat perkembangan teknologi, serta munculnya pola-pola kehidupan sosial, ekonomis, dan politis. Dampak faktor teknologi terhadap kehidupan moderen telah mengubah setting ekologis itu. Malangnya, para pengambil keputusan kadang mengabaikan perubahanperubahan itu dan terlena oleh diktum-diktum lama yang telah usang

Namun demikian, dimensi teknologi tidaklah berpengaruh secara mutlak. Sampai hari ini, sekali lagi, dapat dikemukakan bahwa, faktor geografi masih memainkan peranan penting dalam analisa politik internasional. Berbagai kebijakan luar negeri yang diambil suatu negara pada hakikatnya tidak bisa sepenuhnya mengeleminir pertimbangan-pertimbangan geografi. Setting kewilayahan melahirkan suatu citra tertentu bagi perilaku politik negara dalam berhubungan dengan negara lain. Seperti aktifitas perdagangan, dukungan suara dalam organisasi PBB, keanggotaan dalam organisasi antar pemerintah, serta meningkatnya regionalisme. 


\section{DAFTAR PUSTAKA}

Agnew, J., Place and Politics: The Geographical Mediation of State and Society, Boston: Allen \& Unwin, 1987.

Boyd, Andrew, An Atlas of World Affairs, New York: Praeger, 1964.

Buck, N., The Power of Place: Bringing together Geographical and Sociological Imaginations, Boston and London: Unwin Hyman, 2007.

Cohen, Saul B., Geography and Politics in a World Divided, New York: Random House, 1963.

Cole, John P., Geography of World Affairs, ed. Rev., New Orleans-PelicanBaltimore: Penguin, 1963.

Falk, Richard A., This Endangered Planet, New York: Random House, 1971.

Falk, Richard, dan Cyril Black, ed., The Future of the International Legal Order, Princeton: Princeton University Press, 1969.

Gottmann, J., The Significance of Territory (Charlottesville: University Press of Virginia, 2003.

Kane, Francis X., "Space Age Geopolitics", Orbis, Vol. 14, No. 4 (Winter 1971):911922.

MacKinder, Halford, Democratic Ideals and Reality, New York: W.W. Norton, 1962.

Mellor, R.E.H., Nation State and Territory, London: Routledge, 2009.
Morgenthau, H., Politik di Antara BangsaBangsa, Terj., Jakarta: Yayasan Obor Indonesia, 2012.

Muir, Richard, Political Geography: A New Introduction, Houndmills, Basingstoke, Hampshire and London: MACMILLAN, 2006.

\& Paddison R., Politics, Geography and Behaviour, London and New York: Methuen, 1981.

Rowlands, I., The Politics of Global Atmospheric Change, Manchester: Manchester University Press, 2005.

Russel, Frank M., Theories of International Relations, New York: Appleton Century Crofts, 2003..

Slowe, P., Geography and Political Power, London: Routledge, 2009.

Sprout, Harold, dan Margaret Sprout, Foundations of International Politics, Princeton: D. Van Nostrand Co., 1963.

Taubenfeld, Ritaf, dan Howard J. Taubenfeld, "Some International Implications of Weather Modification Activities", International Organization, 23 (Autum 1969), 808-823.

Viotti, P.R. and Kauppi, M.V., International Relations Theory: Realism, Pluralism, Globalism, 2nd edn, New York: Macmillan, 1993. 